\title{
All-lightweight Aggregate Concrete Frame Structure System of Material Mechanics Performance Test and Research
}

\author{
Yanmin Yang, Runtao Zhang and Bo Qu
}

(School of Civil Engineering,Jilin Jianzhu University,Changchun,130118)

Keywords: The all-lightweight aggregate concrete;design of the mix proportion;the basic mechanical properties.

Abstract. According to the test results of the composition material of the all-lightweight aggregate concrete,design the mix proportion of the all-lightweight aggregate concrete of LC30 and LC35 levels, and make the compressive strength test, the splitting tensile test and the elasticity modulus test,analyze the basic mechanical properties and damage characteristics of the all-lightweight aggregate concrete,play a foundation to design the all-lightweight aggregate concrete frame structure system.

\section{Introduction}

The present Chinese criteria sets the reasonable scope of the density grade of the lightweight aggregate concrete is wider ${ }^{[1-2]}$, and not make the clear requirement. The light concrete as a branch of the lightweight aggregate concrete, is made of light sand as fine aggregate to configure the lightweight aggregate concrete ${ }^{[3]}$, and then to reduce the weight of the structure,To carry out all the research and application of the light concrete has important theoretical basis and engineering value.This topic research the all-lightweight aggregate concrete using shale ceramsite as light coarse aggregate,shale pottery as light aggregate, The apparent density that under the standard condition curing 28 days is less than $1770 \mathrm{~kg} / \mathrm{m}^{3}$.

\section{The all-lightweight aggregate concrete mix proportion design}

\section{The main raw material}

(1)Ceramsite:The shale ceramsite produced by Light weight building materials factory on Tianjin Wu Tong area,the basic physical performance test results are shown in table 1.

Table 1 The physical and mechanical properties of shale ceramsite

\begin{tabular}{c|c|c|c|c|c|c}
\hline $\begin{array}{c}\text { aggregate } \\
\text { type }\end{array}$ & $\begin{array}{c}\text { sieve } \\
\text { analysis } \\
(\mathrm{mm})\end{array}$ & $\begin{array}{c}\text { bulk density } \\
\left(\mathrm{kg} / \mathrm{m}^{3}\right)\end{array}$ & $\begin{array}{c}\text { apparent } \\
\text { density } \\
\left(\mathrm{kg} / \mathrm{m}^{3}\right)\end{array}$ & $\begin{array}{c}\text { porosity } \\
(\%)\end{array}$ & $\begin{array}{c}\text { water } \\
\text { absorption } \\
(\%)\end{array}$ & $\begin{array}{c}\text { numerical tube } \\
\text { pressure } \\
(\mathrm{Mpa})\end{array}$ \\
\hline rubble type & $5-30$ & 765 & 820 & 43 & 5.6 & 7.2 \\
\hline
\end{tabular}

(2)Pottery sand:The shale pottery produced by Yi xing wall materials Co. Limited in Nong'an Country of Jilin province, the basic physical performance test results are shown in table 2.

Table 2 The physical and mechanical properties of shale pottery

\begin{tabular}{c|c|c|c|c|c|c}
\hline $\begin{array}{c}\text { aggregate } \\
\text { type }\end{array}$ & $\begin{array}{c}\text { sieve } \\
\text { analysis } \\
(\mathrm{mm})\end{array}$ & $\begin{array}{c}\text { bulk density } \\
\left(\mathrm{kg} / \mathrm{m}^{3}\right)\end{array}$ & $\begin{array}{c}\text { apparent } \\
\text { density } \\
\left(\mathrm{kg} / \mathrm{m}^{3}\right)\end{array}$ & $\begin{array}{c}\text { porosity } \\
(\%)\end{array}$ & $\begin{array}{c}\text { water absorption } \\
(\%)\end{array}$ & $\begin{array}{c}\text { numerical tube } \\
\text { pressure } \\
(\mathrm{Mpa})\end{array}$ \\
\hline ball type & $3-4$ & 480 & 770 & 38 & 11.2 & 3.6 \\
\hline
\end{tabular}

(3)Cement:Changchun local brand P.O 42.5 cement.

(4)Admixtures:The fly ash,water reducing admixture. 


\section{The all-lightweight aggregate concrete mix proportion design}

There are many factors can affect the all-lightweight aggregate concrete performance and strength, such as the strength of light coarse aggregate and light fine aggregate,cement strength,water cement ratio,cement content,etc.Among them,the strength of light weight aggregate on the lightweight concrete strength plays a main role.Therefore, a reasonable mix proportion design,can not only give full play to The characteristics of the lightweight aggregate is light,but also can reduce the defects of low intensity ${ }^{[4]}$, that due to the material itself reflects the light and porous.Through the orthogonal test,to explore the strength grade most a ccurately LC30 and LC35 levels of the light concrete mix proportion design. The orthogonal test are shown in table 3,comparative analysis is shown in Fig.1.

Table 3 The mixture ratio of full lightweight aggregate concrete

\begin{tabular}{c|c|c|c|c|c|c|c}
\hline number & $\begin{array}{c}\text { cement } \\
(\mathrm{kg})\end{array}$ & $\begin{array}{c}\text { ceramsite } \\
(\mathrm{kg})\end{array}$ & $\begin{array}{c}\text { pottery } \\
\text { sand }(\mathrm{kg})\end{array}$ & $\begin{array}{c}\text { the fly ash } \\
(\mathrm{kg})\end{array}$ & $\begin{array}{c}\text { water } \\
\text { reducing } \\
\text { admixture } \\
(\%)\end{array}$ & W/C & $\begin{array}{c}\text { strength } \\
(\mathrm{Mpa})\end{array}$ \\
\hline P1 & 100 & 120 & 60 & 10 & 0.75 & 0.4 & 37.2 \\
\hline P2 & 100 & 100 & 60 & 10 & 0.75 & 0.4 & 35.5 \\
\hline P3 & 100 & 80 & 60 & 10 & 0.75 & 0.4 & 32.2 \\
\hline P4 & 100 & 120 & 50 & 10 & 0.75 & 0.4 & 36.7 \\
\hline P5 & 100 & 100 & 50 & 10 & 0.75 & 0.4 & 34.5 \\
\hline P6 & 100 & 80 & 50 & 10 & 0.75 & 0.4 & 31.8 \\
\hline P7 & 100 & 120 & 60 & 30 & 0.75 & 0.4 & 37.1 \\
\hline P8 & 100 & 100 & 60 & 30 & 0.75 & 0.4 & 35.7 \\
\hline P9 & 100 & 80 & 60 & 30 & 0.75 & 0.4 & 33.6 \\
\hline
\end{tabular}
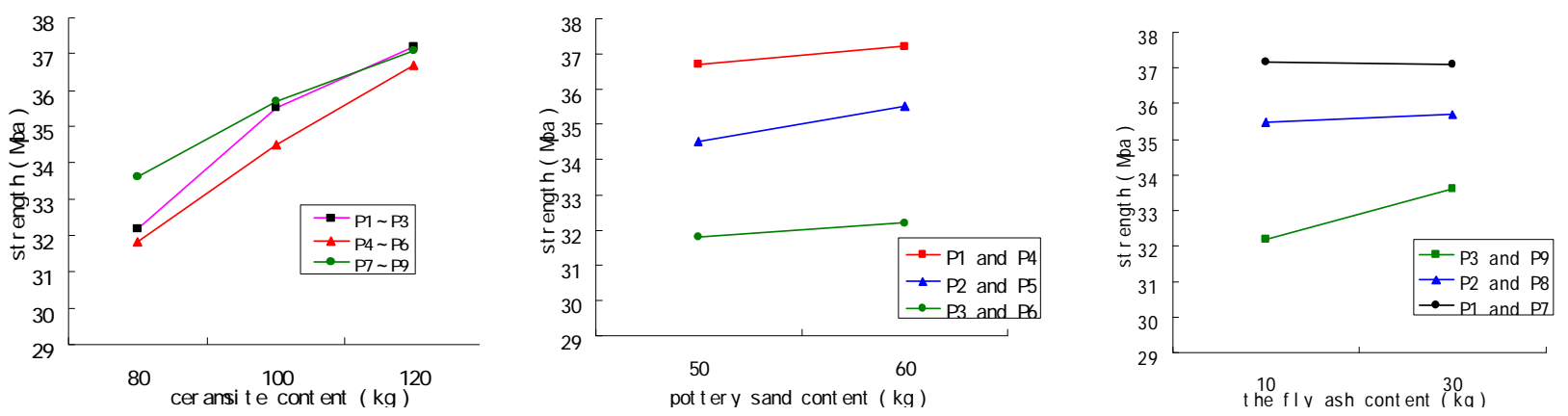

Fig.1. Comparative analysis of the test results

Fig. 1 shows that under the condition of cement dosage, water cement ratio and admixtures of the same,ceramsite content reduced,the all-lightweight aggregate concrete strength decreases;pottery sand content reduced,the all-lightweight aggregate concrete strength decreases; The fly ash content has no obvious effect on strength.According to the test results determine LC30 and LC35 levels optimal mixture ratio of the all-lightweight aggregate concrete,shown in table 4.

Table 4 The optimal mixture ratio of concrete LC30 and LC35 levels

\begin{tabular}{c|c|c|c|c|c|c}
\hline $\begin{array}{c}\text { strength } \\
\text { grade }\end{array}$ & $\begin{array}{c}\text { cement } \\
(\mathrm{kg})\end{array}$ & $\begin{array}{c}\text { ceramsite } \\
(\mathrm{kg})\end{array}$ & $\begin{array}{c}\text { pottery sand } \\
(\mathrm{kg})\end{array}$ & $\begin{array}{c}\text { the fly ash } \\
(\mathrm{kg})\end{array}$ & $\begin{array}{c}\text { water } \\
\text { reducing } \\
\text { d. }\end{array}$ & W/C \\
\hline LC30 & 100 & 80 & 50 & 30 & 0.75 & 0.4 \\
\hline LC35 & 100 & 100 & 60 & 10 & 0.75 & 0.4 \\
\hline
\end{tabular}


The basic mechanics performance test and research of the all-lightweight aggregate concrete

The Dry apparent density and the compressive strength test and research of the all-lightweight aggregate concrete

According to LC30 and LC35 levels of the all-lightweight aggregate concrete mix proportion design,on the basis of the existing specification test method,the dry apparent density and compressive strength test of LC30 and LC35 level of the all-lightweight aggregate concreteare shown in table 5,failure mode is shown in Fig.2.

Table 5 The dry apparent density and compressive strength test of LC30 and LC35 levels

\begin{tabular}{|c|c|c|c|c|c|c|c|c|}
\hline $\begin{array}{l}\text { strength } \\
\text { grade }\end{array}$ & name & 1 & 2 & 3 & 4 & 5 & 6 & average \\
\hline LC30 & \multirow{2}{*}{$\begin{array}{c}\text { dry } \\
\text { apparent } \\
\text { density } \\
\left(\mathrm{kg} / \mathrm{m}^{3}\right)\end{array}$} & 1704 & 1730 & 1718 & 1721 & 1729 & 1700 & 1717 \\
\hline LC35 & & 1739 & 1751 & 1771 & 1780 & 1788 & 1767 & 1766 \\
\hline LC30 & \multirow{2}{*}{$\begin{array}{l}\text { cube } \\
\text { compressiv } \\
\text { e strength } \\
\text { (Mpa) }\end{array}$} & 32.1 & 31.3 & 33.6 & 33.1 & 32.7 & 34.0 & 32.8 \\
\hline LC35 & & 36.1 & 37.1 & 36.9 & 37.9 & 38.6 & 36.6 & 37.2 \\
\hline
\end{tabular}

Splitting and tensile strength tests and researches of the all-lightweight aggregate concrete

For the experiment research of the LC30 and LC35 level of the all-lightweight aggregate concrete, do splitting and tensile strength tests.Tests results are shown in table 6 , failure mode is shown in Fig.3.

Table 6 The splitting and tensile strength tests of LC30 and LC35 levels

\begin{tabular}{c|c|c|c|c}
\hline \multirow{2}{*}{ strength grade } & \multicolumn{3}{|c|}{ splitting and tensile strength ( Mpa ) } & average ( Mpa ) \\
\hline LC30 & 1.8 & 1.98 & 1.85 & 1.88 \\
\hline LC35 & 2.03 & 2.44 & 1.96 & 2.14 \\
\hline
\end{tabular}

The elasticity modulus test and research of the all-lightweight aggregate concrete

Testing the elasticity modulus,respectively, of the all-lightweight aggregate concrete,test results

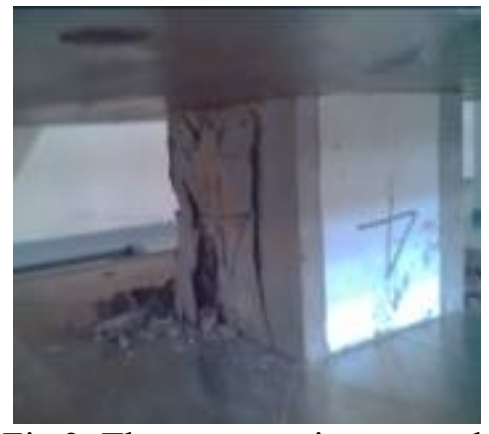

Fig.2. The compressive strength test of full lightweight aggregate concrete

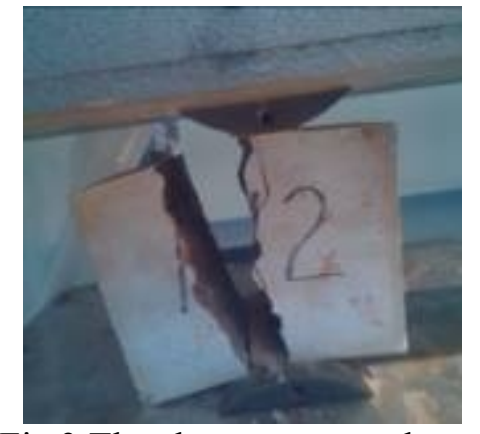

Fig.3.The cleavage strength test of full lightweight aggregate concrete

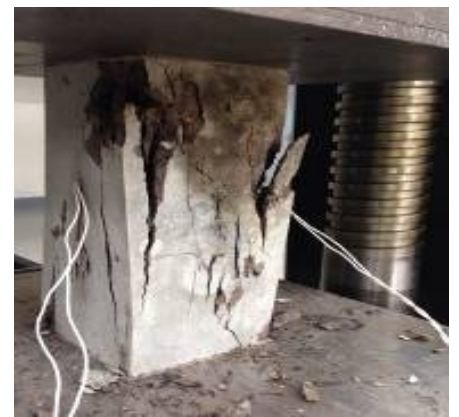

Fig.4. The elastic modulus test of full lightweight aggregate concrete

are shown in table 7, failure mode is shown in Fig. 4.

Table 7 the elasticity modulus test results of LC30 and LC35 levels

\begin{tabular}{c|c|c|c|c}
\hline \multirow{2}{*}{ strength grade } & \multicolumn{3}{|c|}{ the elasticity modulus $\left(\times 10^{4} \mathrm{MPa}\right)$} & average $\left(\times 10^{4} \mathrm{MPa}\right)$ \\
\hline LC30 & 1.71 & 1.78 & 1.73 & 1.74 \\
\hline LC35 & 1.83 & 1.84 & 1.76 & 1.81 \\
\hline
\end{tabular}

\section{Conclusions}

(1)Through the reasonable proportion and trial and error,eventually researched the good 
mechanical properties of LC30 and LC35 level of the all-lightweight aggregate concrete,for the all-lightweight aggregate concrete frame beam-column joints seismic test provides reasonable proportion of the all-lightweight aggregate concrete.

(2)For the experiment research of the LC30 and LC35 level of the all-lightweight aggregate concrete,do the compressive strength test,splitting and tensile strength tests,and he elasticity modulus test.analysis the basic mechanical performance and failure characteristics of the all-lightweight aggregate concrete,for the all-lightweight aggregate concrete frame beam-column joints seismic test provides theoretical basis. The test shows that, the all-lightweight aggregate concrete sets load bearing,energy saving and Insulation in one lightweight construction materials, it can effectively reduce the project cost and the aseismic effect.

(3)Due to the strength and the elasticity modulus of the lightweight aggregate is less than the cement mortar,between the rough surface of the lightweight aggregate and the cement mortar,the cohesive force is strong and some reasons lead to the all-lightweight aggregate concrete is not easy to happen interface damage ${ }^{[5]}$.The test shows that,the all-lightweight aggregate concrete failure mode is aggregate cracking damage.

\section{Acknowledgements}

This work was financially supported by the Jilin Science and Technology Foundation (20150203014SF, 2012200, 2015267).

The authors gratefully acknowledge the Natural Science Foundation of China (No.51378238).

\section{References}

[1] Changjun Li, Xiaojun Qian, Shunbo Zhao.The basic mechanics performance test and research of all-lightweight aggregate concrete[J].Concrete2010(5):79-81.

[2] Shuhe Wang, Zhen Fei, Xiaoqun Xiong,etc.High-strength lightweight aggregate concrete research to the influential factors of mechanical properties[J].Journal of Wuhan University of Technology,2007(9):104-107.

[3] China Academy of Building Research.Technology specification for Lightweight aggregate concrete(JGJ51-2002)[S].China building industry press,2002.

[4] Jiangang Shi.Pumping of the rheological properties of high strength lightweight concrete and its working performance control method[D].Wuhan:Wuhan University of Technology.2007.

[5] A.Carpinteri,A.R.Ingraffea, Yuhui Yang, Zhengyu Huang, Liangfen Wan.Mechanics of concrete fracture[M].Hunan:Hunan University Press.1998. 